\title{
Financial Statement Fraud: A Case Examination Using Beneish Model and Ratio Analysis
}

\author{
Normah Omar, Ridzuan Kunji Koya, Zuraidah Mohd Sanusi, and Nur Aima Shafie
}

\begin{abstract}
Fraud is a major concern for organizations world-wide. Governments and regulators are now focusing on management's responsibility for effective fraud management programs. It is not a matter whether your organization is large or small or what country or industry your organization is in, as long as humans are involved in organizations, the risk of fraud is real. This paper discusses a local case and our analyses are basically subjected to how the fraud was committed and the detection techniques involved. Beneish Model and Ratios Analysis were selected as detection tools in reference to this case. Being the best tools chosen for this case, those techniques will benefit the auditors and other professionals. They can learn these simple, yet effective methods of financial statement fraud detection. Legal implications and its uses will also be discussed in this paper.
\end{abstract}

Index Terms-Fraud management, detection techniques, beneish model, legal implications.

\section{INTRODUCTION}

According to a study conducted by the Association of Certified Fraud Examiners (ACFE), fraudulent financial statements accounts for approximately $10 \%$ of incidents concerning white collar crime. Asset misappropriation and corruption attend to occur at much greater frequency, yet the financial impact of these latter crimes is much less severe. ACFE defines fraud as "the deliberately misrepresentation of financial condition of an enterprise, by intentionally misstating or omitting amounts disclosures in the financial statements so as to deceive their users". Fraud's effect on an organization's bottom line is just the tip of the iceberg. Without a proactive approach to combating fraud, the ability to gain and to maintain customer loyalty is almost non-existent [1]. Additionally, organizations are said to lose an average of six percent of their annual revenue to fraud and abuse committed by internal employees. A proactive approach to fraud identification is the only way to address and to lessen the effect of fraud on organizations today. Sophisticated techniques and methods are utilized to build a financial profile of a suspected fraudster [2].

Manuscript received October 14, 2013; revised December 15, 2013. This work was supported in part by the Fundamental Research Grant Scheme, Malaysian Ministry of Education and Research Management Institute, Universiti Teknologi MARA.

N. Omar and Z. Mohd Sanusi are with the Accounting Research Institute, Universiti Teknologi MARA, 40450 Shah Alam, Selangor, Malaysia (e-mail: normah645@salam.uitm.edu.my, zuraidahms@salam.uitm.edu.my).

R. Kunji Koya was with the Universiti Teknologi MARA (e-mail: normah645@salam.uitm.edu.my).

N. A. Shafie is with the Faculty of Accountancy, University Teknologi MARA, 40450, Shah Alam, Malaysia (e-mail: ishaiman87@gmail.com).

\section{Case Study-Megan Media Holdings Berhad} (MMHB)

\section{A. Company's Background}

The company which is to be abbreviated as MMHB was established in early 1994. The principal activities of the company started from producing plastic injection components to a range of electronics and automotive parts. Recognizing the future prospects of the data storage media industry in 1996, MMHB ventured into the manufacturing of 3.5" multi-function disk (MFD) and videotapes through its subsidiary company MTSB. In the 1999, MTSB expanded into the manufacturing of compact disc-recordable (CD-R) and digital versatile disc-recordable (DVD-R). It became the first Malaysian company to receive pioneer status from the Ministry of International Trade and Industries for manufacturing magnetic and optical data storage products. On August 8, 2000, MMHB was listed onto the Second Board of the Kuala Lumpur Stock Exchange. MMHB's entire share capital transferred from the Second Board to Main Board of the Exchange under the "Industrial Products" sector with effect Tuesday, December 3, 2002. MMHB aggressive market strategy has resulted in thecompany achieving a prominent footing as the largest manufacturer of CD-R and DVD-R in the country.

\section{B. Case Background}

$\mathrm{Mr} \mathrm{KH}$, the former Financial Controller of the company, has abetted MMHB who had with intent to deceive, furnished false statements to Bursa Malaysia. The false statements were in relation to MMHB's revenue figures in its Financial Statements for the year ended 30 April 2006 and Quarterly Reports on Consolidated Results for the Financial Period ended 31 July 2006, 31 October 2006 and 31 January 2007 respectively. At the material time, $\mathrm{Mr} \mathrm{KH}$ was the personal assistant to the Executive Chairman of MMHB. The Executive Chairman, Mr MA was also charged under the same section as $\mathrm{Mr} \mathrm{KH}$, for furnishing false information on the revenue figure for MMHB's third quarter 2007 financial figure.

\section{How Fraud Was Committed}

MMHB's woes surfaced in early May when its two subsidiaries - MTSB and Singapore-based MPL - defaulted on a RM47 million payment to bondholders. A preliminary report on MTSB by a group of private forensic accountants of FH Company revealed that "substantial irregularities" and that the company's financial position had been "materially misstated". The findings showed that MTSB's suspect transactions included a RM211mil deposit paid for 13 production lines that could be fictitious, in addition to the fictitious trading that resulted in receivables totaling 
RM334.3mil. It also revealed that MTSB's assets could potentially fall short by RM456mil. It was also discovered that the payments to all trading creditors were actually made to other parties in an attempt to channel cash out of MTSB. MMHB reported an unaudited loss of RM1.3 billion for its fiscal year ended April 2007 from a profit of RM60 million the year before. MMHB's total equity stands in deficit to the tune of nearly RM797 million and its net liability per share is nearly RM4 compared to a net tangible asset per share of RM2.31 in FY 2006.

\section{ANALYSIS}

\section{A. Beneish Model}

Created by Professor MessodBeneish, the M-Score is a mathematical model that uses eight financial ratios to identify whether a company has manipulated its earnings [3].The variables are constructed from the company's financial statements and create a score to describe the degree to which the earnings have been manipulated.In many ways it is similar to the Altman Z-Score, but it is focused on detecting earnings manipulationrather than bankruptcy. There are eight variables taken into account for developing the M-Score, as listed below:

- DSRI - Days' sales in receivable index

- GMI - Gross margin index

- AQI - Asset quality index

- SGI - Sales growth index

- DEPI - Depreciation index

- SGAI - Sales and general and administrative expenses index

- LVGI - Leverage index

- TATA - Total accruals to total assets

M-Score that based on the 8 variables as above, calculated by using the formula of:

$M=-4.84+(D S R I+G M I+A Q I+S G I+D E P I+S G A I+T A T A+L V G I)$

By using this approach, total M-Score calculated with the figure of bigger than-2.22suggests that the company had manipulated their earnings. According to the ratio calculated from MMHB's financial statement, the input variables are stated in Table I below.

\begin{tabular}{lrr}
\multicolumn{3}{c}{ TABLE I: INPUT VARIABLES } \\
\hline \multicolumn{1}{c}{ Input Variables } & \multicolumn{1}{c}{2006} & \multicolumn{1}{c}{2005} \\
\hline Net Sales & $1,034,797$ & 904,696 \\
CGS & 885,525 & 781,284 \\
Net Receivables & 81,760 & 62,705 \\
Current Assets (CA) & 671534 & 370,991 \\
PPE (Net) & 660,983 & 712,071 \\
Depreciation & 121,465 & 116,492 \\
Total Assets & $1,389,094$ & $1,145,265$ \\
SGA Expense & 100,334 & 530,031 \\
Net Income (before Xitems) & 86,792 & 68,634 \\
CFO (Cash flow from operations) & 109,063 & 129,729 \\
Current Liabilities & 330,236 & 443,275 \\
Long-term Debt & 597,153 & 701,990 \\
\hline \hline
\end{tabular}

Following the input variables, indices are calculated so that the derived variables can be used for the M-Score calculation using the given formula. Table II illustrates:

Derived variables:

Total $M$-Score: 0.863

TABLE II: DERIVED VARIABLES

\begin{tabular}{ll}
\hline \hline DSRI & 1.140 \\
GMI & 0.946 \\
AQI & 0.750 \\
SGI & 1.144 \\
DEPI & 0.906 \\
SGAI & 0.165 \\
Total Accruals/TA & -0.016 \\
LVGI & 0.668 \\
\hline \hline
\end{tabular}

Based on the formula from the mathematical model, the study managed to clarify that the M-Score for MMHB is larger than -2.22, thus gave an indication of MMHB had manipulated its earnings. Ratio analysis will be further continued as another tool in detection of fraud, particularly involving earnings management to substantiate and to strengthen our investigation that MMHB had committed the same.

\section{B. Ratio Analysis}

The ratio analysis is used to observe 4 main areas of the financial indicators, namely Profitability, Operating

Efficiency, Liquidity \& Coverage and Fundingstructure. The result has been concluded in the Financial Factor table as stated in Table III below:

\begin{tabular}{lccc}
\multicolumn{4}{c}{ TABLE III: FINANCIAL FACTORS } \\
\hline \multicolumn{1}{c}{ Indicators } & 2005 & 2006 & 2007 \\
\hline $\begin{array}{l}\text { Profit before Interest and } \\
\text { Tax ("PBIT") Margin (\%) }\end{array}$ & $10.75 \%$ & $12.64 \%$ & \\
$\begin{array}{l}\text { Return on Capital } \\
\text { Employed, (ROCE) (\%) }\end{array}$ & $9.19 \%$ & $9.85 \%$ & $(928.70 \%)$ \\
$\begin{array}{l}\text { Days Trade Debtors (as } \\
\text { days turnover) }\end{array}$ & 106.18 & 123.15 & 25.94 \\
$\begin{array}{l}\text { Days Inventory (as cost of } \\
\text { sales) }\end{array}$ & 16.95 & 17.98 & 33.86 \\
Current Ratio (times) & 0.84 & 1.12 & 0.13 \\
Quick Ratio (times) & 0.76 & 1.05 & 0.07 \\
$\begin{array}{l}\text { Short Term Cash } \\
\text { Adequacy (times) }\end{array}$ & 0.08 & 0.10 & 0.01 \\
$\begin{array}{l}\text { Interest Coverage (times) } \\
\text { Gearing (times) }\end{array}$ & 3.34 & 2.87 & $(24.12)$ \\
\hline \hline
\end{tabular}

PBIT has significantly increased compared to the years mainly due to significant increase on the revenue for the year and this scenario might be caused by the economic downturn in 2007 and the impact of restated for the financial report (Profitability). The impact from low sales has also turns ROCE into negative level and it might shows that the company did not fully utilize its capital. Days Trade Debtors has increased, same goes to Days Inventory (Operating efficiency). It might show a tight cash flow for this company and the current asset might not be insufficient to cover the obligation or debt. This situation was showed by the Quick Ratio and Short Term Cash Adequacy (Liquidity). The lower Interest Coverage ratio, the more the company is burdened by debt expenses. Hence the scenario looks worse as showed in the table above.The Gearing ratio has significantly decreased and it might show that the company was holding a large 
amount of debts that might not be able to be settled on time. It might also shows that the company had used external fund in running the business (Coverage and Funding).

\section{DISCUSSIONS}

The offence made by MMHB was charged under section 122B (a)(bb) of the Securities Industry Act 1983 which carries a maximum RM3 million fine or 10 years jail, or both, on conviction. Mr KK pleaded guilty to one of four charges he was facing and was fined RM350,000 in default of a year's imprisonment. MMHB could not sort out its financial woes, which were not surprising considering that a large chunk of its past revenues had been falsified. It failed to submit its regularisation plan to the authorities according to the PN17 timeframe and was delisted in April 2008. The call for an effective method to identifying earnings manipulation has increased with each exposed accounting scandal. In our investigation, the limitation of the tools used (Beneish model and financial ratio) is that the limited information provided in the financial statements and the footnotes to the accounts. However, the Bursa Malaysia and Securities Commission announcements and newspaper reports had provided additional information that implicates MMHB involvement in financial fraud. The material misstatement in their financial reporting had brought to the collapse of MMHB [4, $5,6]$. The Beneish model and financial ratio can be used as a tool for detecting financial fraud. These tools had result in significant differences and proved that the company commits an earnings manipulation.

\section{A. Uses and Implications}

Financial statement fraud causes the biggest losses. In the US for example, the improved control environment under Sarbanes-Oxley will certainly affect the numbers going forward. But financial fraud will likely always rank number one in losses. Both auditors and investigators can use findings by Professor Messod Daniel Beneish. Auditors can use Bonefish's ratios to help carry out the AIS 240 requirements to perform audits to be reasonably assured that financial statements are free from material misstatement. In the other hand, investigators brought in to investigate a suspected fraud can use this tool to help focus the investigation [7]. Numbers from different reporting period of the income statement and the balance sheet produce results that red flag the problem. The Beneish's ratio measures sales growth, the quality of assets and gross margins, the progression of receivables versus sales and the ratio of general and administrative expenses. The probability of earnings management goes higher with unusual increases in receivables, deteriorating gross margin, decreasing assets quality, sales growth and increasing accruals. At the end, the ratio results point to whether there is likely a problem.

In the MMHB's case study, at first, our investigation used the Beneish model to identify if there is any potential fraud in their financial statement. The M-score is higher than-2.22 confirm that Megan Media had manipulated their earnings. We then further our investigation by using the financial ratio analysis for three consecutive years (year end 2005, 2006 and 2007). The operating efficiency ratio analysis show that the company recorded fictitious revenue amounting to RM 198,727. Therefore, these tools used in our investigation confirm that the company involve in manipulating their financial statements.

\section{ACKNOWLEDGMENT}

We would like to thank Accounting Research Institute (ARI), Universiti Teknologi MARA, and Fundamental Research Grant Scheme in collaboration with the Ministry of Higher Education Malaysia (MOHE) in providing the financial support for this research project. We are indeed very grateful for the grant, without which we would not be able to carry out the research.

\section{REFERENCES}

[1] C. A. Conan. (2002). Fraud and forensic accounting in a digital environment. White paper for the Institute for fraud prevention. [Online]. http://www.theifp.org/research-grants/IFP-Whitepaper-4.pdf

[2] L. Gao and R. P. Srivastava, "The anatomy of management fraud schemes: Analysis and implication," Indian Accounting Review, vol. 15, no. 1, June, 2011.

[3] M. D. Beneish, "Detecting GAAP Violation: Implications for Assessing Earnings Management Among Firms with Extreme Financial Performance," Journal of Accounting and Public Policy, vol 16, no. 3, pp. 271-309, 1997.

[4] Securities Commission. [Online]. Available: www.sc.com.my

[5] Bursa Malaysia. [Online]. Available:www.bursamalaysia.com

[6] The Star. (2007). Megan Media defaults on RM894m bank facilities. [Online]. Available: http://biz.thestar.com.my/news/story.asp?file=/2007/6/14/business/18 024994\&sec=business

[7] M. D. Beneish, "Incentives and penalties related to earnings overstatements that violate GAAP forthcoming," The Accounting Review, vol. 74, no. 4, October 1999.

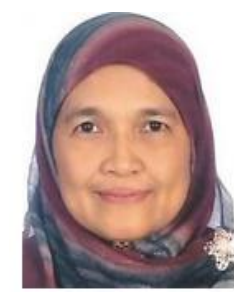

Normah Omar started her academic career as a lecturer at the Faculty of Accountancy, UiTM since January 1983. She was first posted at the UiTM Dungun Campus for one semester before being transferred to UiTM Sarawak, where she served for another four years. In 1987, she was transferred back to UiTM Shah Alam. In, 1989, she secured a scholarship to pursue her $\mathrm{PhD}$ program in management accounting at the Manchester Metropolitan University, United Kingdom.She completed her doctoral degree in 1993. As an academician, Dr Normah has held many administrative positions such as program leader, program coordinator, research coordinator, coordinator of Quality Initiatives and deputy dean. Effective January 2006, Prof. Dr .Normah Omar has been appointed as the director of Accounting Research Institute. Currently she is a member of the university senate and a project manager to the vice chancellor special project (VCSP) entitled "Strategic Alliances with Top Notch Research Centres \& Top Notch Researchers".

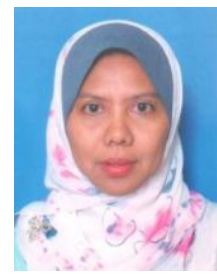

Zuraidah Mohd Sanusi is currently the deputy director of the Accounting Research Institute (ARI) (Postgraduate \& Innovation), Universiti Teknologi MARA and lecturer of Faculty of Accountancy. Her current research interest is in the area of forensic accounting, financial criminology, auditing and corporate governance. 